\title{
Penerapan Model Pembelajaran Discovery Learning Berbantuan Program Cabri 3D untuk Meningkatkan Hasil Belajar Peserta Didik Materi Pokok Dimensi Tiga
}

\author{
Lisbeth Hutapea \\ SMAN 8 B.Lampung, Jl. Laksamana Malahayati Teluk Betung Bandar Lampung, Indonesia. \\ *Correaponding Author. E-mail: lisbethhutapea@gmail.com
}

\begin{abstract}
Abstrak
Penelitian ini bertujuan untuk meningkatkan hasil belajar peserta didik pada materi dimensi tiga dengan model Discovery Learning berbantuan program CABRI 3D. Jenis penelitian yang digunakan yaitu Penelitian Tindakan Kelas. Hasil penelitian menunjukkan bahwa model pembelajaran discovery learning berbantuan media Cabri 3D dapat meningkatkan hasil belajar peserta didik. Hal ini terbukti dengan adanya peningkatan dari pra siklus dengan nilai rata-rata kelas 63,06 meningkat menjadi 63,89 pada siklus I dan pada siklus II rata-rata nya meningkat kembali menjadi 83,13. Ketuntasan belajar klasikal juga meningkat dari 9,26\% pada pra siklus menjadi 38,89 \% pada siklus I dan meningkat kembali pada siklus II menjadi $80 \%$.
\end{abstract}

Kata kunci: Cabri 3; Discovery Learning; Hasil Belajar

\section{Abstract}

This study aims to improve student learning outcomes in the three dimensional material with the Discovery Learning model assisted by the 3D CABRI program. The type of research used is Classroom Action Research. The results showed that discovery learning learning models assisted by Cabri 3D media can improve student learning outcomes. This is evidenced by an increase from the pre cycle with the class average value of 63.06 increasing to 63.89 in the first cycle and in the second cycle the average increased again to 83.13. Classical learning completeness also increased from $9.26 \%$ in the pre-cycle to $38.89 \%$ in the first cycle and increased again in the second cycle to $80 \%$.

Keywords: Cabri 3; Discovery Learning; Learning outcomes

\section{PENDAHULUAN}

Komponen penting dalam pendidikan adalah pendidik dan peserta didik. Interaksi yang tepat antara pendidik dengan peserta didik sangat diharapkan untuk meningkatkan kualitas pembelajaran yang diperoleh peserta didik. Selain itu, kualitas pembelajaran juga akan berdampak pula pada hasil belajar peserta didik. Kualitas pembelajaran yang tinggi akan meningkatkan hasil belajar peserta didik dan begitu pula sebaliknya. Komponen lain yang terdapat pada pendidikan adalah isi atau materi pendidikan. Salah satu materi pembelajaran matematika adalah materi dimensi tiga yang merupakan bagian dari materi geometri yang diajarkan di kelas X pada jenjang pendidikan menengah atas. Sebenarnya materi dimensi tiga sudah mulai diperkenalkan kepada peserta didik sejak jenjang sekolah dasar dalam bentuk yang lebih sederhana. Meskipun begitu, masih dijumpai kesulitan pada peserta didik. Permasalahan itu diperjelas dengan masih banyaknya peserta didik yang belum mencapai KKM untuk materi dimensi tiga. Berdasarkan permasalahan tersebut, maka diperlukan solusi untuk mengatasi kesulitan yang dialami peserta didik. salah satunya adalah dengan menggunakan model dan media pembelajaran yang sesuai.

Model pembelajaran yang digunakan harus sesuai dengan kondisi 
peserta didik dan materi yang diajarkan. Salah satu model pembelajaran yang tepat untuk materi dimensi tiga adalah model discovery learning. Discovery learning merupakan model pembelajaran untuk menemukan sesuatu yang bermakna dalam pembelajaran. Prosedur discovery learning yaitu: stimulus (stimulator), identifikasi masalah (problem statement), pengumpulan data (data collecting), pengolahan data (data processing), verifikasi (verification), dan generalisasi (generalization). Melalui tahapan-tahapan pada model discovery tersebut, diharapkan pemahaman konsep peserta didik akan meningkat, sehingga hasil belajarnya juga akan meningkat. Selain model pembelajaran discovery, dibutuhkan juga suatu alat atau media yang dapat membantu visualisasi dan pemahaman peserta didik terhadap dimensi tiga. Salah satu pilihan media yang tepat adalah dengan menggunakan Cabri 3D. Cabri 3D merupakan suatu program berbasis komputer yang didesain untuk pembelajaran geometri. Program ini bersifat dinamis sehingga memungkinkan peserta didik untuk secara langsung memanipulasi objekobjek tiga dimensi. Dengan andanya program ini, peserta didik dapat lebih mudah memahami konsep-konsep, khususnya konsep dimensi tiga.

Berdasarkan

beberapa penelitian yang telah dilakukan sebelumnya model Discovery Learning telah banyak dilakukan pada berbagai penelitian untuk mendukung proses pembelajaran. (Anggoro, 2016; Asri \& Noer, 2015; Haryanti \& Ardi Saputro, 2016; Imamah \& Toheri, 2014; Jumhariyani, 2016; Kristin \& Rahayu, 2016; Maduretno, Sarwanto, \& Sunarno, 2016; Muzaki, Slamin, \& Dafik, 2015; Persada, 2016; Ramadhani, 2017; Salo, 2016; Sari, Ridlo, \& Utami, 2016) serta beberapa penelitian dalam upaya meningkatkan hasil belajar siswa. (Amin, 2017; Bey \& Asriani, 2013; Erlinda, 2016; Hasanah, 2016; Lipianto et al., 2013; Lusianti, 2013; Mahanal, Darmawan, Corebima, \& Zubaidah, 2009; Mayliana \& Sofyan, 2013; Sains \& Purwanto, 2014; Sumarni \& Susanti, 2016; Weni \& Isnani, 2016; Yulianti, An'nur, \& Wati, 2014) Namun, belum adanya penelitian yang menerapkan model Discovery Learning berbantuan program CABRI 3D dalam meningkatkan hasil belajar siswa.

Berdasarkan penelitian terdahulu keterbaruan penelitian ini terletak pada penerapan model Discovery Learning berbantuan program CABRI 3D dalam meningkatkan hasil belajar siswa. Maka, tujuan penelitian ini adalah untuk meningkatkan hasil belajar peserta didik pada materi dimensi tiga dengan model Discovery Learning berbantuan program CABRI 3D

\section{METODE PENELITIAN}

Jenis Penelitian yang digunakan adalah Penelitian Tindakan Kelas. Penelitian Tindakan Kelas meruakan pemecahan masalah yang dimulai dari perencanaan, pelaksanaan, pengamatan, dan menganalisis data. Penelitian dilakukan pada kelas X SMA N 2 Bandar Lampung. Teknik pengumpulan data menggunakan teknik observasi, dokumentasi dan tes.

Teknik Analisa Data dalam penelitian ini diolah dengan analisis deskriptif, data mengenai hasil belajar diambil dari kemampuan kognitif siswa dalam mengerjakan soal evaluasi pada tiap akhir siklus. Data tersebut kemudian dianalisis menggunakan rumus sebagai menghitung rata-rata hasilbelajar. Untuk menghitung ratarata digunakan rumus

$$
\bar{x}=\frac{\sum x}{N}
$$


Desimal, 2 (1), 2019 - 79

Lisbeth Hutapes

Keterangan:

$\bar{x}=$ Rata-rata Nilai

$\sum x=$ jumlah seluruh nilai

$N=$ Jumlah pesertadidik

Menghitung ketuntasan belajar individu menggunakan rumus

Nilai $=\frac{\sum \text { Skor yang diperole }}{\sum \text { Skor maksimum }} \times 100$

Peserta didik dikatakan tuntas secara individu jika nilai mereka mencapai minimal 75. Sedangkan untuk ketuntasan belajar klasikal menggunakan rumus sebagai berikut:

Ketuntasan Klasikal $=$

$\frac{\sum \text { Peserta didik yang tuntas }}{\text { P Peserta didik }} \times 100 \%$

Keberhasilan kelas dilihat dari jumlah peserta didik yang mampu menyelesaikan atau mencapai minimum 75 sekurang kurangnya $75 \%$ dari jumlah peserta didik di kelas tersebut. Indikator ketercapaian dalam penelitian ini adalah Rata-rata hasil belajar peserta didik $\geq$ 75, Persentase ketuntasan hasil belajar secara klasikal minimal $75 \%$ dari jumlah peserta didik yang mencapai KKM.

\section{HASIL DAN PEMBAHASAN}

Pembahasan pada penelitian tindakan kelas ini didasarkan pada hasil penelitian yang dilanjutkan pada hasil refleksi dari setiap tindakan yang dilakukan pada tiap siklus. Secara umum, proses pembelajaran pada setiap siklus sudah berjalan dengan baik sesuai dengan langkah-langkah yang telah direncanakan. Proses pembelajaran yang berlangsung dalam dua siklus selalu mengalami peningkatan kualitas.
Secara terperinci, analisis hasil penelitian tiap siklus dijabarkan sebagai berikut :

\section{Pra Siklus}

Hasil belajar peserta didik pada pra siklus ini dilihat dari nilai ulangan harian peserta didik materi pokok dimensi tiga pada tahun ajaran sebelumnya. Hasil belajar tersebut diolah dan disajikan pada Tabel 1 dan Gambar 1 dan Gambar 2 berikut:

Tabel 1. Rata-rata dan Ketuntasan Hasil Belajar

\begin{tabular}{ccc}
\hline No & Indikator & Pra Siklus \\
1 & Rata-rata & 63,06 \\
2 & Ketuntasan Klasikal & $9,26 \%$ \\
\hline
\end{tabular}

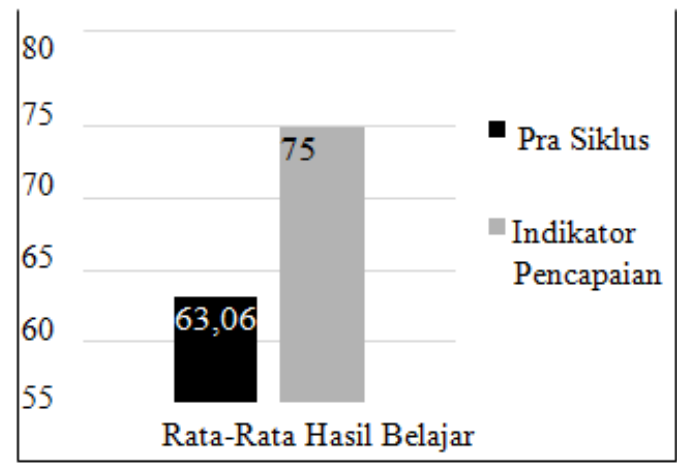

Grafik 1. Grafik rata-rata hasil belajar peserta didik pra siklus

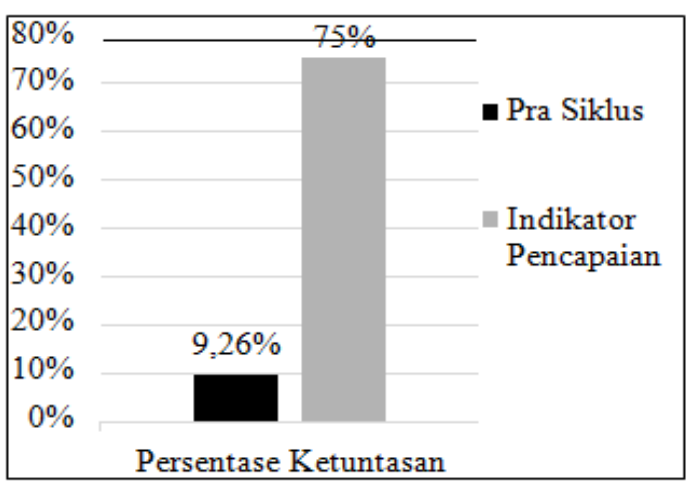

Gambar 2. Grafik Rata-rata Hasil Bellajar Peserta Didik Klasikal Pra Siklus 


\section{Desimal, 2 (1), 2019 - 80}

Lisbeth Hutapes

Berdasarkan data yang diperoleh, hasil belajar peserta didik pada pra siklus masih rendah. Hal ini dilihat dari nilai rata-rata kelas yang masih di bawah KKM yang ditentukan. Nilai peserta didik materi Dimensi Tiga pada tahun ajaran 2013/ 2014 menunjukkan bahwa dari 54 peserta didik dari tiga kelas, hanya terdapat 5 peserta didik yang nilainya mencapai KKM. Sedangkan nilai rata-rata kelasnya adalah 63,06.

Sehingga ketuntasan klasikal yang dicapai hanya 9,26 \%. Uraian di atas menunjukkan bahwa pembelajaran pada tahun sebelumnya masih rendah, karena masih banyak peserta didik yang belum memenuhi KKM yang telah ditetapkan. Menurut Pujiati, pembelajaran yang sering dilaksanakan adalah ceramah dan latihan soal. Media belajar yang digunakan adalah dengan menggambar bangun dimensi tiga di papan tulis sehingga hal ini membutuhkan waktu yang lebih lama. Selain itu, kemampuan peserta didik dalam mengabstraksi dan menguasai model permasalahan masih kurang. Hal ini ditunjukkan dengan ketika diberikan soal yang berbeda dengan contoh yang dibahas di kelas, peserta didik akan kesulitan. Dengan pembelajaran yang seperti itu, menjadikan hasil belajar peserta didik rendah. Melalui pengkajian pada pembelajaran sebelumnya yang masih belum mencapai ketuntasan, maka perlu diadakan perubahan pada metode dan model pembelajaran yang digunakan guru. Oleh sebab itu, perlu adanya model dan metode yang mampu meningkatkan hasil belajar peserta didik. Salah satunya adalah yang ditawaran peneliti, yaitu dengan model discovery learning dan berbantuan program Cabri 3D.

\section{Siklus I}

Berdasarkan hasil observasi dan pelaksanaan tindakan pada siklus I dengan model pembelajaran discovery learning berbantuan program Cabri 3D pada materi jarak dalam dimensi tiga menunjukkan bahwa nilai hasil belajar peserta didik mengalami peningkatan yang cukup baik. Hal ini ditunjukkan dengan hasil rata-rata kelas yang pada pra siklus sebesar 63,06 dengan persentase ketuntasan 9,26\% meningkat menjadi 63,89 dengan persentase ketuntasan $38,89 \%$ pada siklus I. Dari 20 peserta didik kelas X-1, terdapat 2 peserta didik yang tidak mengikuti tes evaluasi karena tidak masuk. Sehingga data yang diolah hanya bersumber dari 18 peserta didik. Dari 18 peserta didik yang mengikuti tes evaluasi, terdapat 7 peserta didik yang tuntas dan 11 peserta didik yang tidak tuntas. Namun demikian, pada siklus I ini rata-rata hasil belajar dan persentase ketuntasan klasikal belum mencapai indikator keberhasilan, sehingga model pembelajaran discovery learning berbantuan program Cabri 3D pada materi dimensi tiga harus dilanjutkan lagi pada siklus II.

Hasil observasi pada siklus I menunjukkan bahwa terdapat beberapa kekurangan yang dilakukan oleh guru maupun peserta didik. guru belum maksimal dalam menerapkan langkahlangkah pada discovery learning , seperti langkah identifikasi masalah, pengumpulan data, dan generalisasi karena masih lebih aktif guru dalam proses pembelajaran. Kemudian guru belum dapat mengkondisikan waktu dengan baik sesuai dengan RPP. Pada proses pembelajaran, peran guru masih dominan. Guru belum dapat menarik perhatian peserta didik untuk berpartisipasi penuh dalam pembelajaran dimensi tiga. 


\section{Desimal, 2 (1), 2019 - 81}

Lisbeth Hutapes

Berdasarkan observasi terhadap peserta didik, peserta didik belum terbiasa belajar secara aktif dan mandiri, sehingga pelaksanaan pembelajaran discovery learning belum maksimal. Sebagian besar peserta didik masih canggung untuk mengajukan pertanyaan ataupun menyampaikan pendapat, sehingga harus dimintai satu persatu untuk mengajukan pertanyaan ataupun pendapatnya. Peserta didik masih menyesuaikan dengan program Cabri 3D. Peserta didik masih belum terbiasa berfikir mandiri, sehingga guru masih membimbing apa yang harus dikerjakan oleh peserta didik. Dari hasil evaluasi pada siklus I, maka hasil belajar peserta didik pada siklus I dapat dilihat pada Tabel 2 dan Gambar 3 dan Gambar 4 di bawah ini.

Tabel 2. Rata-rata dan ketuntasan hasil belajar siklus I

\begin{tabular}{clc}
\hline No & \multicolumn{1}{c}{ Indikator } & Siklus I \\
1 & Rata-rata & 63,89 \\
2 & Ketuntasan Klasikal & $38,89 \%$ \\
\hline
\end{tabular}

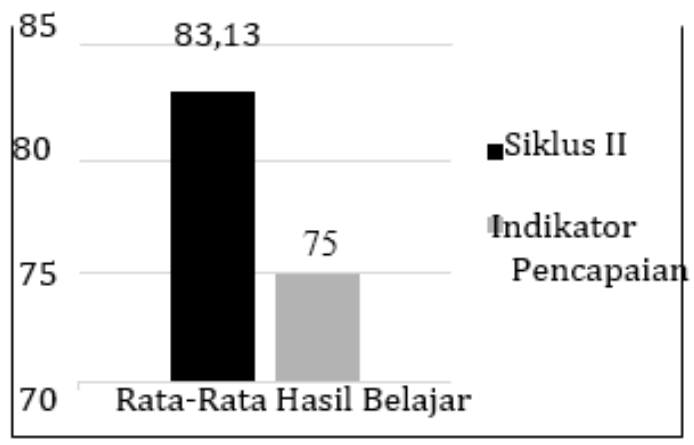

Gambar 3. Rata-rata hasil belajar peserta didik siklus II

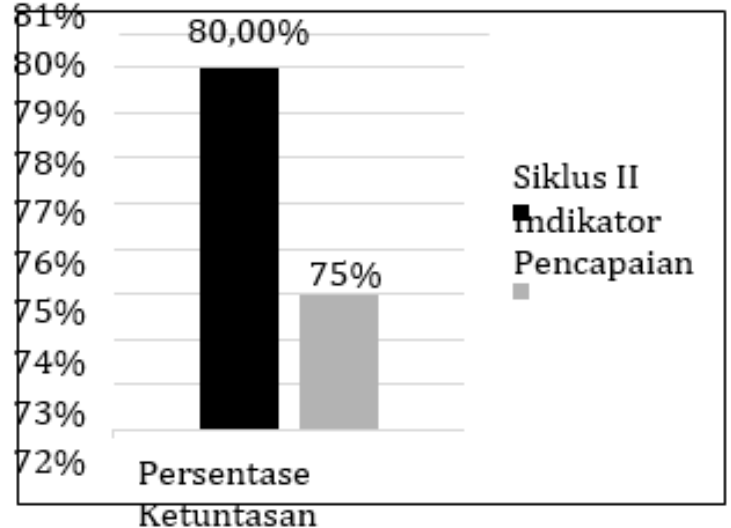

Gambar 4. Persentase ketuntasan belajar klasikal siklus II

Berdasarkan analisis data dari setiap siklus, dapat dilihat bahwa pada pra siklus rata-rata hasil belajar peserta didik kelas $\mathrm{X}$ materi Dimensi Tiga hanya sebesar 63,06 dengan ketuntasan klasikal sebesar 9,26\%. Hasil tersebut sangat rendah karena sekolah menerapkan standar KKM sebesar 75 dan dari 54 peserta didik kelas $\mathrm{X}$ hanya 5 peserta didik yang tuntas. Pada siklus I, rata-rata hasil belajar peserta didik mengalami peningkatan dari pra siklus, yaitu menjadi 63,89 dengan persentase ketuntasan klasikal sebesar $38,89 \%$. Kenaikan rata-rata hasil belajar dari pra siklus ke siklus I tidak cukup besar, yaitu hanya 0,83 poin. Namun demikian, ketuntasan klasikalnya mengalami peningkatan yang signifikan, yaitu sebesar $29,63 \%$ dari pra siklus. Kemudian pada siklus II rata-rata hasil belajar peserta didik meningkat menjadi 83,13 dengan ketuntasan klasikal sebesar 80\%. Pada siklus II terjadi peningkatan yang signifikan dimana rata-rata hasil belajar peserta didik meningkat sebesar 19,24 poin dan ketuntasan klasikalnya meningkat sebesar 41,11\%.

Adanya peningkatan hasil belajar peserta didik pada setiap siklusnya ini ditunjukkan dari bagaimana perlakuan guru selama proses pembelajaran. Selama pembelajaran, guru dengan menggunakan 


\section{Desimal, 2 (1), 2019 - 82 \\ Lisbeth Hutapes}

model pembelajaran discovery learning memberikan ruang kepada peserta didik untuk lebih aktif dalam bertanya dan mencari pemecahan masalah. Hal ini sesuai dengan teori Bruner yang menyatakan bahwa belajar penemuan sesuai dengan proses pencarian pengetahuan yang aktif dilakukan oleh manusia, sehingga dengan sendirinya proses tersebut akan memberikan hasil yang terbaik.

Hasil ini juga didukung dengan digunakannya program Cabri 3D, dimana dengan menggunakan media ini, maka peserta didik lebih terbantu dalam mengabstarksikan model dimensi tiga. Penggunaan media ini membantu peserta didik pada tahapan ikonik sesuai dengan tahapan pembelajaran dari Bruner. Kemudian, berkaitan dengan teori Van Hiele, selama proses pembelajaran, materi disusun dan disampaikan secara runtut sesuai dengan tingkatan geometri Van Hiele, sehingga peserta didik lebih mudah dalam menguasai materi yang disampaikan. Selain itu, guru juga membimbing peserta didik agar selalu mengaitkan materi yang akan dipelajari dengan materi yang telah dipelajari sebelumnya. Hal ini membantu peserta didik untuk lebih mudah dalam memahami materi yang disampaikan. Hal ini sesuai dengan teori yang dikemukakan oleh David Ausubel, yaitu konsep baru atau informasi baru harus dikaitkan dengan konsep-konsep yang sudah ada dalam struktur kognitif peserta didik. Dari ketiga teori tersebut, terbukti bahwa penggunaan model pembelajaran discovery learning dengan berbantuan program Cabri 3D pada materi dimensi tiga dapat mempengaruhi hasil belajar peserta didik kelas X-1 SMAN 8 Bandar Lampung pada materi dimensi tiga, yaitu mengalami peningkatan pada setiap siklusnya. Untuk lebih jelasnya, data perkembangan peserta didik setiap siklus disajikan dalam Tabel 3 dan Gambar 5 dan
Gambar 6 di bawah ini.

Tabel 3 Perbandingan rata-rata dan ketuntasan hasil belajar pra siklus, siklus I, dan siklus II

\begin{tabular}{|c|c|c|c|c|}
\hline No & Indikator & $\begin{array}{c}\text { Pra } \\
\text { Siklus }\end{array}$ & Siklus I & $\begin{array}{c}\text { Siklus } \\
\text { II }\end{array}$ \\
\hline 1 & Rata-rata & 63,06 & 63,89 & 83,12 \\
\hline 2 & $\begin{array}{c}\text { Ketuntasan } \\
\text { Klasikal }\end{array}$ & $9,26 \%$ & $38,89 \%$ & $80 \%$ \\
\hline
\end{tabular}

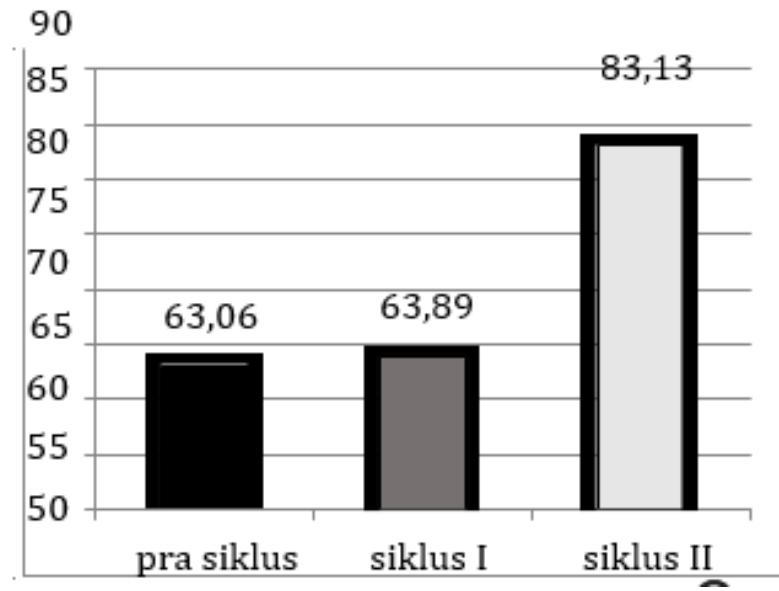

Gambar 5. Grafik rata-rata hasil belajar peserta didik pada setiap siklus

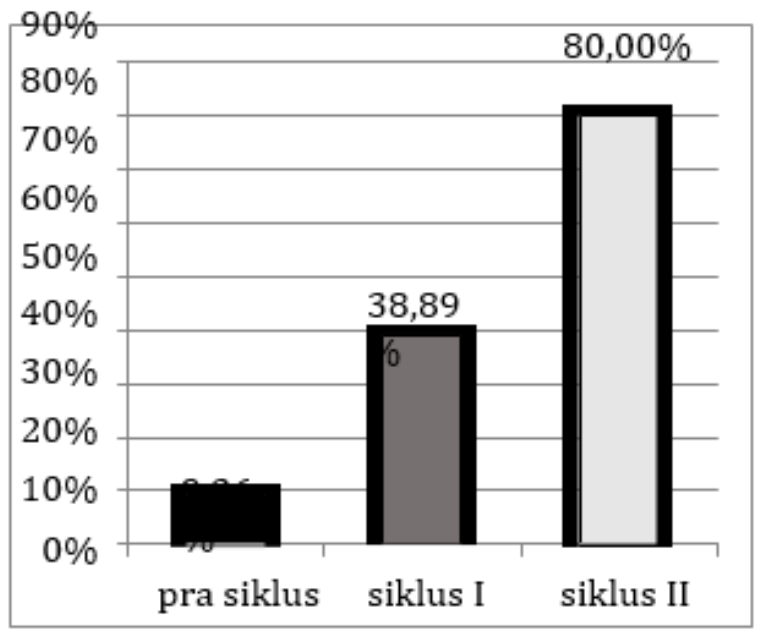

Gambar 6. Grafik ketuntasan belajar klasikal pada setiap siklus

Berdasarkan Tabel 3, Gambar 5, dan 


\section{Desimal, 2 (1), 2019 - 83}

Lisbeth Hutapes

Gambar 6 dapat dilihat bahwa hasil belajar peserta didik kelas X-2 pada materi dimensi tiga mengalami peningkatan dari setiap siklusnya. Pada siklus II indikator penelitian telah tercapai, yaitu rata-rata hasil belajar $\geq 75$ dan ketuntasan klasikal $\geq 75 \%$, Sehingga dapat disimpulkan bahwa penelitian ini telah berhasil. Dengan menggunakan model pembelajaran discovery learning berbantuan media Cabri 3D, hasil belajar peserta didik selama proses pembelajaran materi dimensi tiga mengalami peningkatan. Hal ini meninjukkan bahwa penerapan model pembelajaran discovery learning berbantuan program Cabri 3D dapat meningkatkan hasil belajar peserta didik materi pokok dimensi tiga kelas X-2 SMAN 8

Penelitian ini sejalan dengan penelitian sebelumnya oleh Eka Novita Sari, Saiful Ridlo, dan Nur Rahayu Utami yang menyimpulkan bahwa penerapan model pembelajaran discovery dengan mind mapping berpengaruh terhadap hasil belajar kognitif, afektif, dan psikomotor siswa pada materi sel di SMA. (Sari et al., 2016) serta penelitian oleh Yosef Patandung yang menyimpulkan bahwa terdapat engaruh signifikan penerapan model pembelajaran discovery terhadap motivasi siswa kelas VII SD Mannuruki dalam pembelajaran sains. Hasil penelitian ini diharapkan dapat menjadi referensi bagi guru dalam mengembangkan pembelajaran matematika terutama pada materi Dimensi Tiga.

\section{SIMPULAN DAN SARAN}

Berdasarkan hasil pembahasan dapat disimpulkan bahwa model pembelajaran discovery learning berbantuan media Cabri 3D dapat meningkatkan hasil belajar peserta didik. Hal ini terbukti dengan adanya peningkatan dari pra siklus dengan nilai rata-rata kelas 63,06 meningkat menjadi
63,89 pada siklus I dan pada siklus II ratarata nya meningkat kembali menjadi 83,13 . Ketuntasan belajar klasikal juga meningkat dari 9,26 \% pada pra siklus menjadi 38,89 \% pada siklus I dan meningkat kembali pada siklus II menjadi $80 \%$.

Berdasarkan kesimpulan penelitian, ada beberapa hal yang perlu peneliti sarankan yaitu model pembelajaran discovery learning dapat digunakan sebagai alternatif dalam proses belajar mengajar khususnya mata pelajaran matematika untuk meningkatkan hasil belajar, serta untuk penelitian selanjutnya yaitu agar dapat mencoba menggunakan model-model pembelajaran lain untuk memaksimalkan berbagai aspek dalam pembelajaran matematika

\section{DAFTAR PUSTAKA}

Amin, A. K. (2017). Kajian Konseptual Model Pembelajaran Blended Learning berbasis Web untuk Meningkatkan Hasil Belajar dan Motivasi Belajar. Jurnal Pendidikan Edutama, 4(2), 51-64.

Anggoro, B. S. (2016). Meningkatkan Kemampuan Generalisasi Matematis Melalui Discovery Learning dan Model Pembelajaran Peer Led Guided Inquiry. Al-Jabar: Jurnal Pendidikan Matematika, 7(1), 11-20.

Asri, E. Y., \& Noer, S. H. (2015). Guided Discovery Learning dalam Pembelajaran Matematika. In Prosiding Seminar Nasional Matematika dan Pendidikan Matematika (pp. 891-896).

Bey, A., \& Asriani. (2013). Penerapan Pembelajaran Problem Solving untuk Meningkatkan Aktivitas dan Hasil Belajar Matematika pada Materi SPLDV. Jurnal Pendidikan Matematika, 4(2), 223-239.

Erlinda, Y. (2016). Upaya Meningkatkan Hasil Belajar Matematika Perkalia 


\section{Desimal, 2 (1), 2019 - 84}

Lisbeth Hutapes

Bersusun Kesamping Melalui Metode Drill Bagi Anak Tunagrahita Ringan. Jurnal Konseling Dan Pendidikan, 4(3), 18-23.

Haryanti, F., \& Ardi Saputro, B. (2016). Pengambangan Modul Matematika Berbasis Discovery Learning Berbantuan Flipbook Maker Untuk Meningkatkan Kemampuan Pemahaman Konsep Pada Materi Segitiga. Jurnal Pendidikan Matematika, I(2), 147-161.

Hasanah, U. (2016). Penerapan Strategi Pembelajaran Mind Mapping Untuk Meningkatkan Hasil Belajar Peserta Didik Pada Mata Pelajaran Fiqih Kelas VII A MTS Nurul Islam Air Bakoman Kabupaten Tanggamus. Al-Idarah: Jurnal Kependidikan Islam, 6(2), 4160.

Imamah, F. U., \& Toheri. (2014). Pengaruh Penggunaan Kombinasi Metode Pembelajaran Discovery Learning Dan Brain Storming Terhadap Kemampuan Pemecahan Masalah Pada Pokok Bahasan Himpunan. EduMa, 3(1), 120-137.

Jumhariyani. (2016). Pengaruh Metode Penemuan Terbimbing Dan Kemampuan Berpikir Kritis Terhadap Kemampuan Matematika Siswa Kelas IV SD Sekecamatan SetiaBudi Jakarta Selatan. Jurnal Pendidikan Dasar, 7(1), 62-73.

Kristin, F., \& Rahayu, D. (2016). Pengaruh Penerapan Model Pembelajaran Discovery Learning Terhadap Hasil Belajar IPS Pada Siswa Kelas 4 SD. Scholaria, 6(1), 84-92.

Kuswana, W. S. (2012). Taksonomi Kognitif: Perkembangan Ragam Berfikir. Bandung: Remaja Rosdakarya.

Lipianto, D., Budiarto, M. T., Matematika, J., Surabaya, U. N., Matematika, J., \& Surabaya, U. N. (2013). Analisis kesalahan siswa dalam menyelesakan soal yang berhubungan dengan persegi dan persegipanjang berdasarkan taksonomi solo plus pada kelas vii. Mathedunesa, 2(1).

Lusianti, M. (2013). Penerapan Metode

Diskusi Syndicate Group Untuk Meningkatkan Aktivitas dan Hasil Belajar Pada Pokok Bahasan Mendeskripsikan Hubungan Antara Kelangkaan Sumber Daya Dengan Kebutuhan Manusia yang Tidak Terbatas. Economic Education Analysis Journal, 2(3), 82-87.

Maduretno, T. W., Sarwanto, \& Sunarno, W. (2016). Pembelajaran IPA Dengan Pendekatan Saintifik Menggunakan Model Learning Cycle dan Discovery Learning Ditinjau Dari Aktivitas Dan Motivasi Belajar Siswa Terhadap Prestasi Belajar. JPFK, 2(1), 1-11.

Mahanal, S., Darmawan, E., Corebima, ) A D, \& Zubaidah, S. (2009). Pengaruh Pembelajaran Project Based Learning (PjBL) pada Materi Ekosistem terhadap Sikap dan Hasil Belajar Siswa SMAN 2 Malang.

Mayliana, E., \& Sofyan, H. (2013). Penerapan Accelerated Learning Dengan Pendekatan SAVI Untuk Meningkatkan Motivasi dan Hasil Belajar Kompetensi Menggambar Busana. Jurnal Pendidikan Vokasi, 3(1), 14-28.

Muzaki, L., Slamin, \& Dafik. (2015). Pengembangan Perangkat Pembelajaran berbasis Metode Guided Discovery Learning Berbantuan E-Learning dengan Aplikasi Atutor pada Pokok Bahasan Lingkaran. Pancaran, 3(2), 25-34.

Persada, A. R. (2016). Pengaruh Model Pembelajaran Penemuan (Discovery Learning) Terhadap Kemampuan Koneksi Matematika Siswa. EduMa, 5(2), 23-33.

Ramadhani, R. (2017). Kemampuan Pemecahan Masalah Matematika Siswa SMA Melalui Guided Discovery Learning Berbantuan Autograph. 


\section{Desimal, 2 (1), 2019 - 85}

Lisbeth Hutapes

JPPM, 10(2), 72-81.

Sains, K. P., \& Purwanto, A. (2014). Implementasi Model Learning Cycle 5E Disertai LKS Untuk Meningkatkan Aktivitas, Keterampilan Proses Sains dan Hasil Belajar Biologi. Jurnal Pendidikan Biologi, 5(1), 1-11.

Salo, Y. A. (2016). Pengaruh metode Discovery Learning Terhadap Keaktifan Belajar Siswa. Jurnal Penelitian Pendidikan, 16(3), 297304.

Sari, E. N., Ridlo, S., \& Utami, N. R. (2016). Pengaruh Model Pembelajaran Discovery Learning Dengan Mind Mapping Terhadap Hasil Belajar Siswa Pada Materi SEL di SMA. Unnes Science Education Journal, 5(3), 1403-1407.

Sumarni, \& Susanti, N. (2016). Penerapan Metode Pembelajaran Kooperatif Tipe Student Teams Achievement Divisions (STAD ) Untuk Meningkatkan Hasil Belajar Mahasiswa Pada Mata Kuliah Perencanaan Pembelajaran Ekonomi. Economica, 4(1), 109-123.

Weni, D. M., \& Isnani, G. (2016). Meningkatkan Hasil Belajar Siswa dengan Pengembangan Media Pembelajaran E-Learning Berbasis Blog. Jurnal Pendidikan Bisnis Dan Manajemen, 2(2), 114-123.

Yulianti, H., An'nur, S., \& Wati, M. (2014). Meningkatkan Hasil Belajar Siswa Pada Materi Ajar Listrik Statis Dengan Pendekatan Problem Posing. Berkala Ilmiah Pendidikan Fisika, 2(3), 244252. 